\title{
Se hurtigt om jeres referencer mangler DOI-henvisninger
}

Den angivne sti til Reference Linking er pt. ikke tilgængelig. Brug følgende URL: https://apps.crossref.org/SimpleTextQuery

Hvis I som tidsskriftsejere ønsker at tilmelde jer CrossRef's DOI-service skriver I samtidig under på, at I vil sørge for, at alle referencer, der måtte have et DOI og som citeres i de publicerede artikler, indføjes med et sådant i de enkelte referencelister - husk at referencelisterne også skal indsættes som metadata ${ }^{1}$. I er derfor nødt til at tjekke om artiklernes forfattere har sørget for, at DOl'erne står anført. Det kan tage sig lidt uoverskueligt ud, specielt hvis der følger en lang litteraturliste med. Heldigvis stiller CrossRef et værktøj til rådighed, der gør processen meget overskuelig.

På CrossRef's hjemmeside - http://crossref.org/ - finder man værktøjet via 'Find a service' > 'Reference Linking'

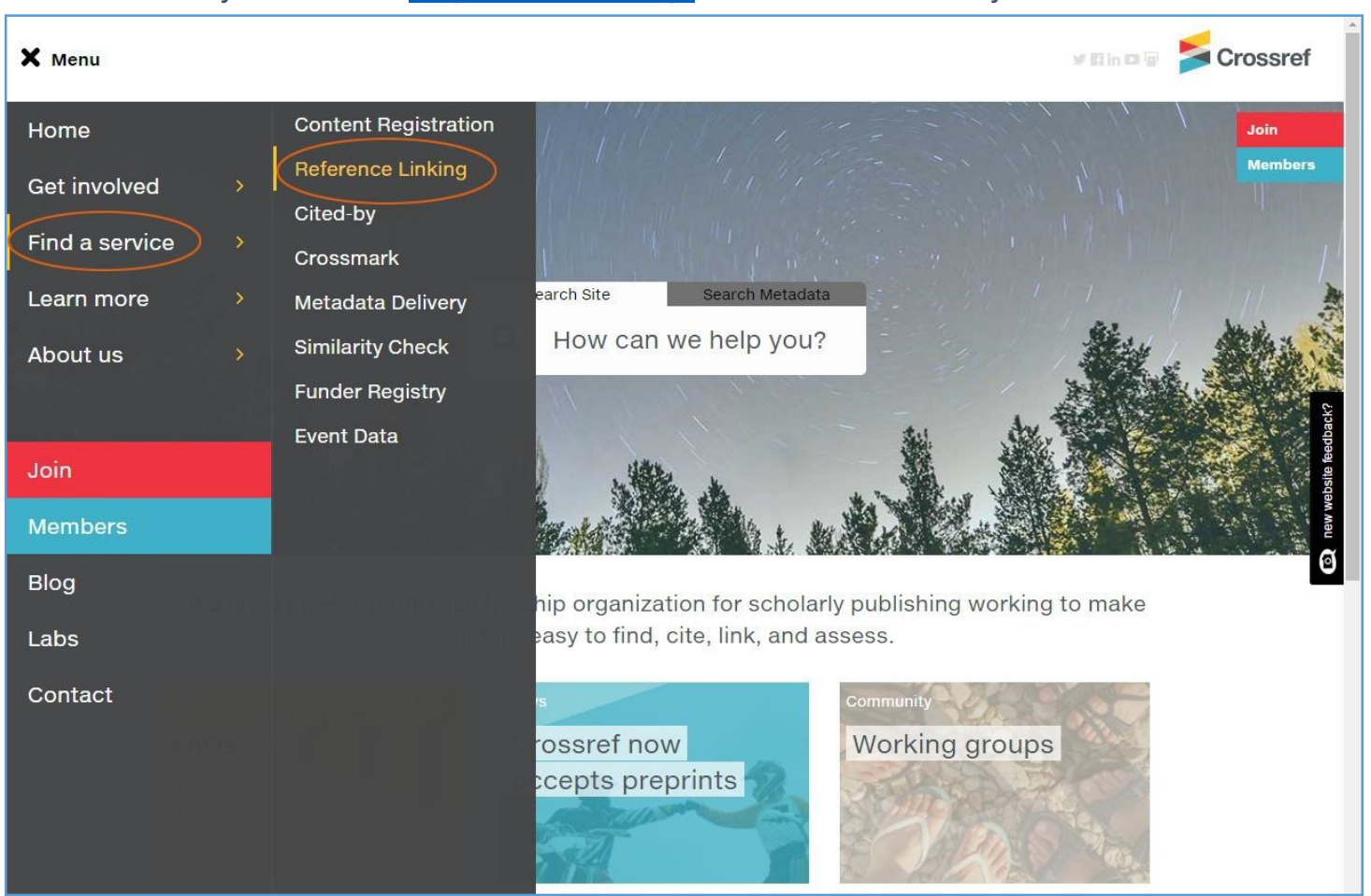

${ }^{1}$ Se: Frederiksen, N.E., Thestrup, J.: "Hvordan indsætter redaktøren/tidsskriftschefen referencer i overensstemmelse med CrossRef's krav?" i OJS på dansk 6. årg., nr. 5, 2015 DOI: http://dx.doi.org/10.7146/ojssb.v6i5.20603 
Lidt nede på siden 'Reference Linking' finder man under afsnittet 'FAQs' linket til værktøjet - 'Simple Text Query Form'.

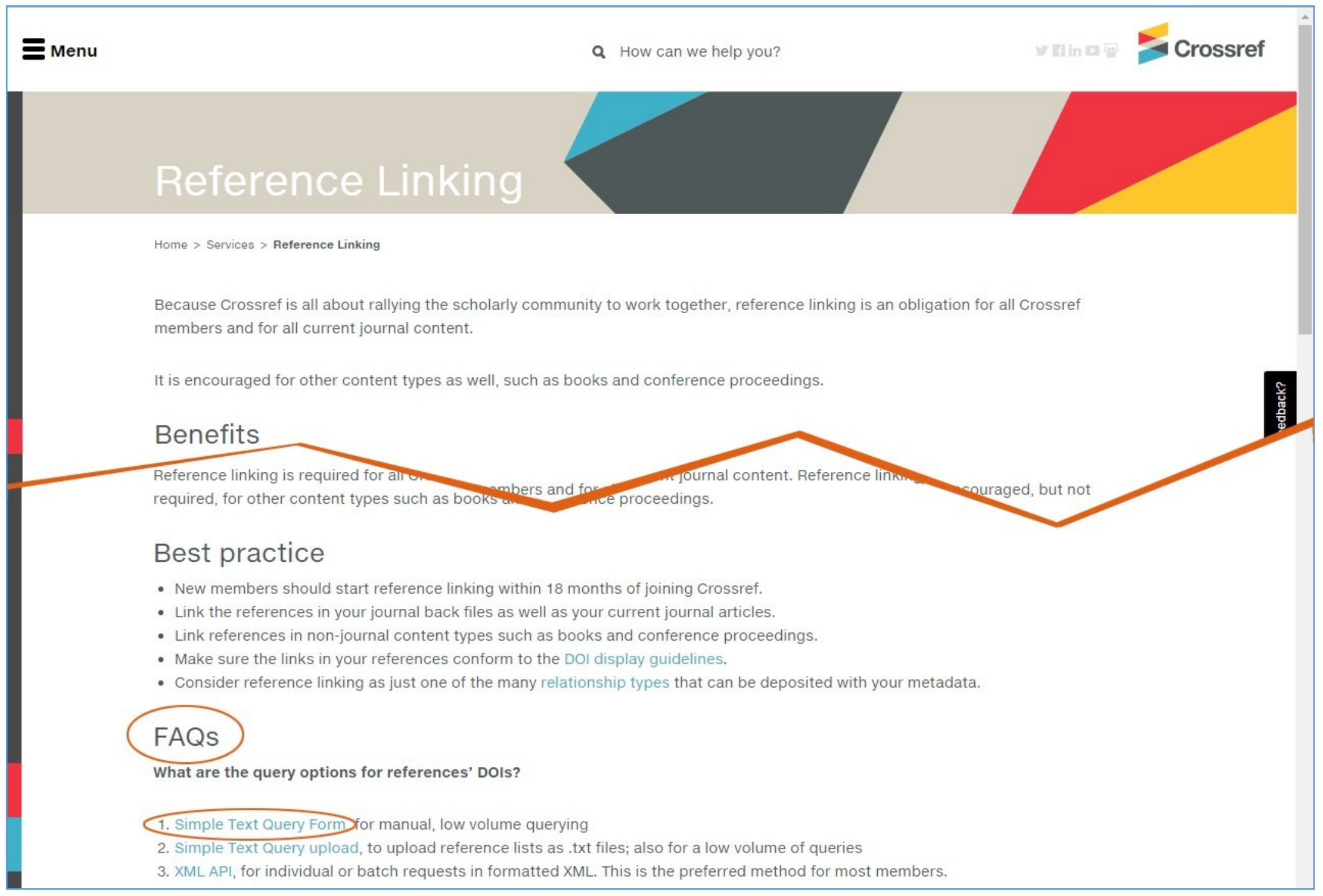


Inden værktøjet kan tages i brug skal man først oprette en konto. Den er er gratis. Dette sker via linket 'request an account'

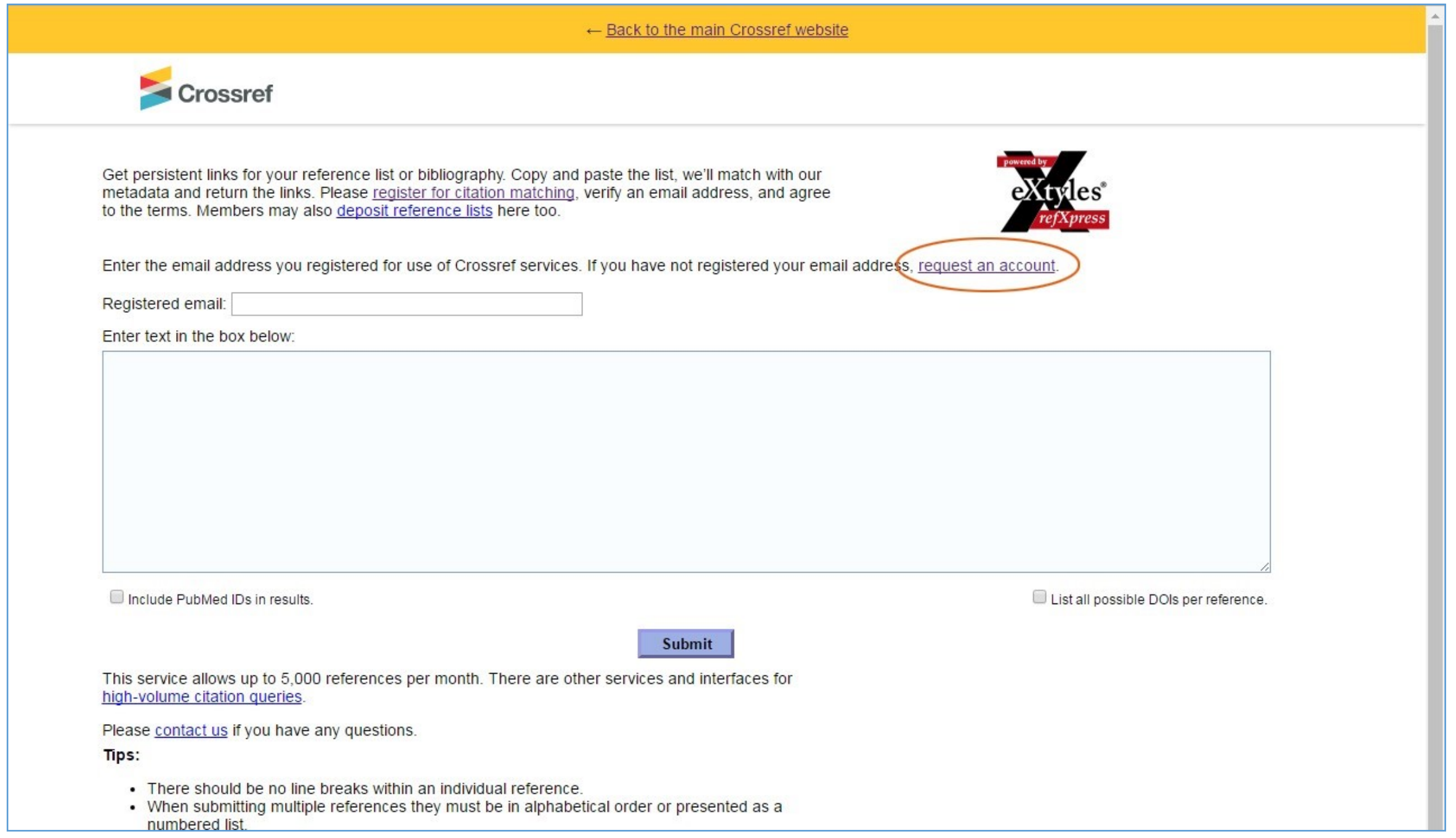


På den fremkomne side udfyldes de markerede felter og der afsluttes med 'Submit'.

\section{$\leftarrow$ Back to the main Crossref website}

\section{Crossref}

\section{Crossref Query Services Account Request Form}

Crossref provides various web interfaces for key query services. Registered Crossref Members, Libraries and Affiliates may use the web interfaces with their previously supplied system account credentials. The Crossref Query Services interfaces are:

* SimpleText Query

* OpenURL

If you are not a Crossref member with account credentials, you may register for an account here. This account registration service is available at no charge to certain entities (please see the detailed terms and conditions below).

The purpose of requiring an account for using Crossref Query Services is simply to monitor usage to balance system demand and to identify problems.

If you have any questions please email support@crossref.org

To create an account, you will need to provide your email address. You will receive an email for verific ation and to activate your account.

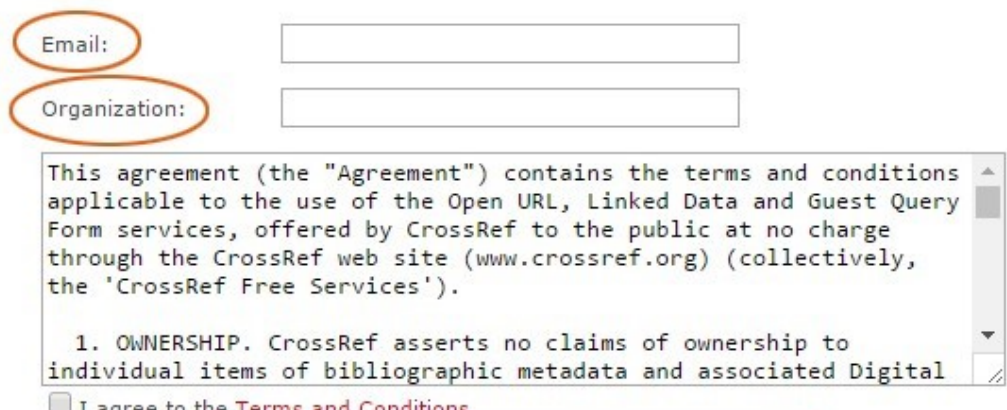

individual items of bibliographic metadata and associated Digital

I agree to the Terms and Conditions

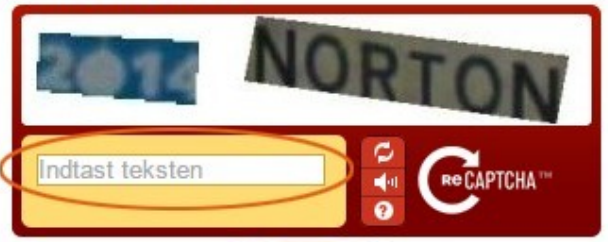


Efterfølgende sendes der automatisk en mail med link til side, hvor man skal bekræfte tilmeldingen.

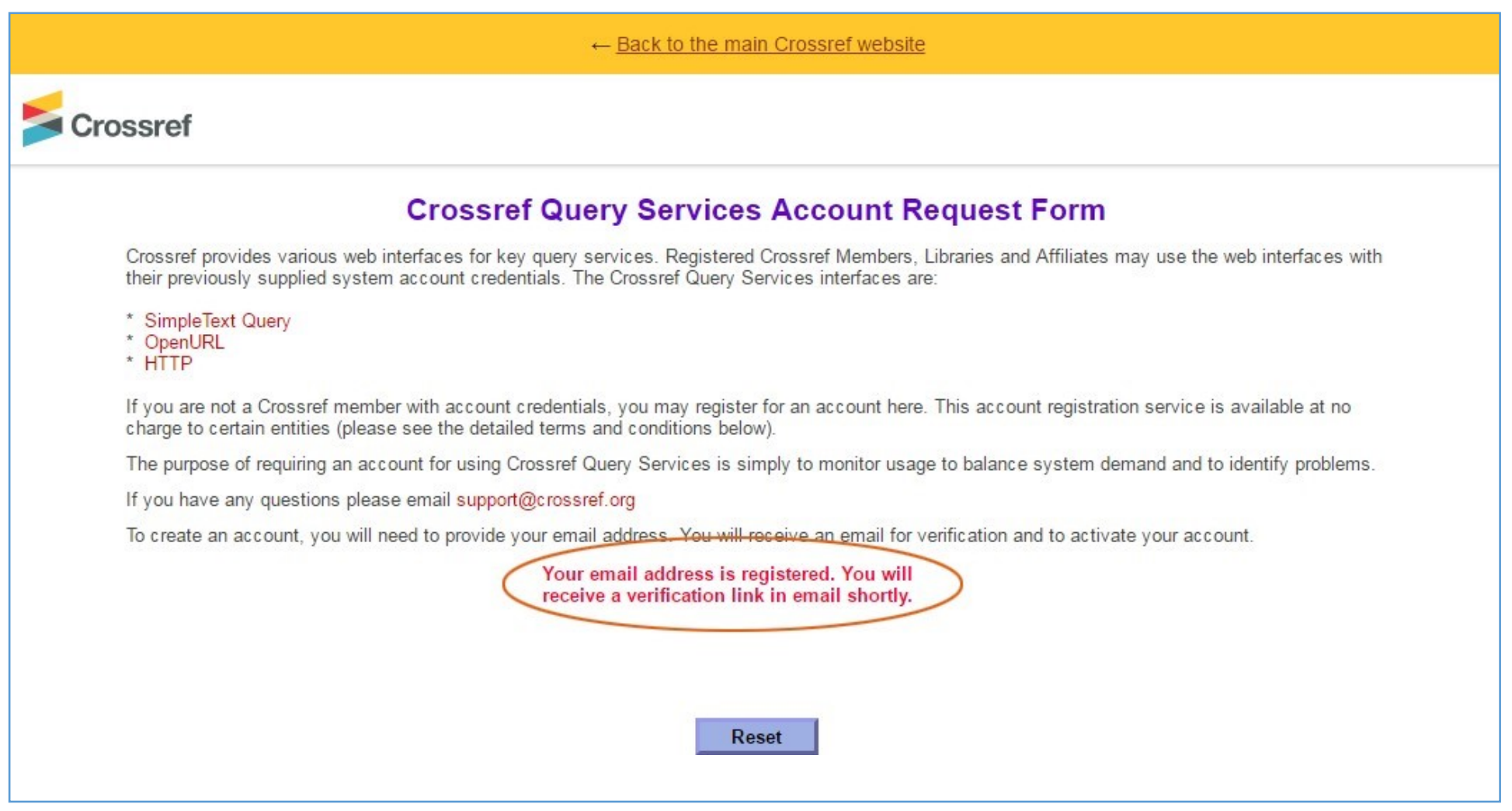

Eq Svar [ę Svar til alle

to $16-02-2017$ 09:49

support@crossref.org

Crossref Services Account request verification

Til Niels Erik Frederiksen

Action Items

+ Hent flere apps

Please click the following link or paste it into a browser to activate your Crossref Services account.

http://www.crossref.org/requestaccount?email=nef@kb.dk\&verify 
Når Captcha-teksten er skrevet ind og der er klikket på Submit-knappen ........

\section{$\leftarrow$ Back to the main Crossref website}

\section{Crossref}

\section{Crossref Query Services Account Request Form}

Crossref provides various web interfaces for key query services. Registered Crossref Members, Libraries and Affiliates may use the web interfaces with their previously supplied system account credentials. The Crossref Query Services interfaces are:

* SimpleText Query

* OpenURL

* HTTP

If you are not a Crossref member with account credentials, you may register for an account here. This account registration service is available at no charge to certain entities (please see the detailed terms and conditions below)

The purpose of requiring an account for using Crossref Query Services is simply to monitor usage to balance system demand and to identify problems

If you have any questions please email support@crossref.org

To create an account, you will need to provide your email addreos. You will receive-an-mail for verification and to activate your account.

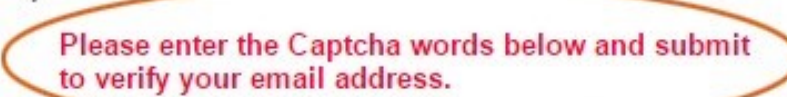

to verify your email address.

Email: nef@kb.dk

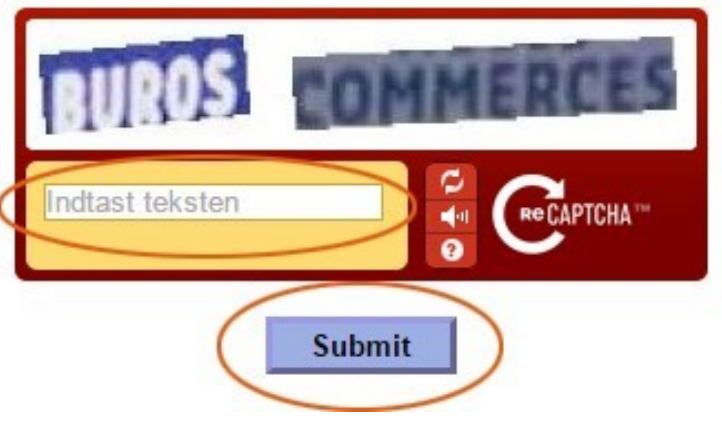


... kan værktøjet tages i brug.

Indsæt litteraturlisten som vist og klik på 'Submit'. Husk at litteraturlisten skal udformes efter gældende regler for formatering, f.eks. APA, Harvard eller Vancouver.

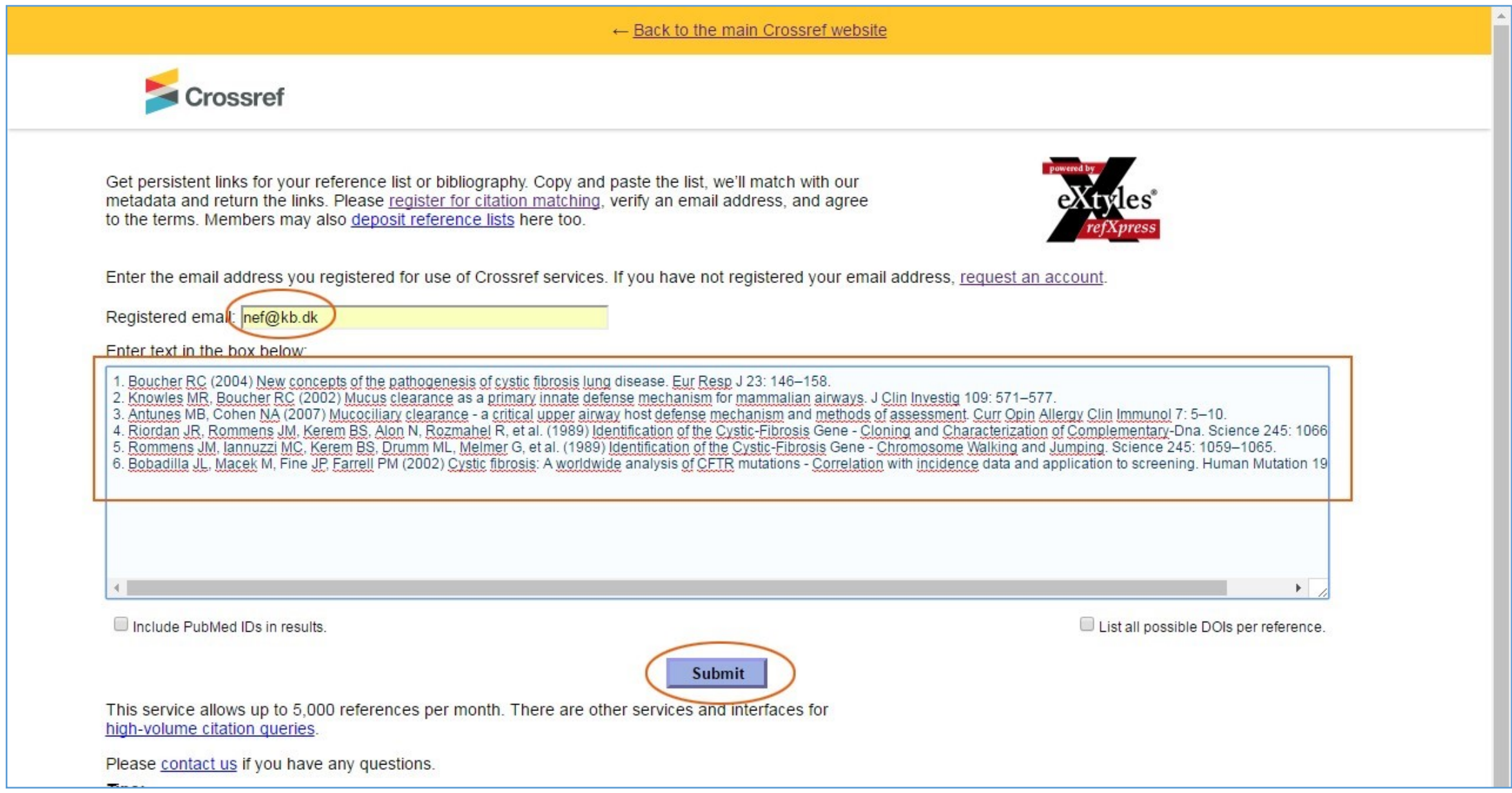


Efter at have klikket på Submit-knappen fremkommer et resultat, hvor de referencer der har et DOI nu fremstår med dette anført sidst i referencen.

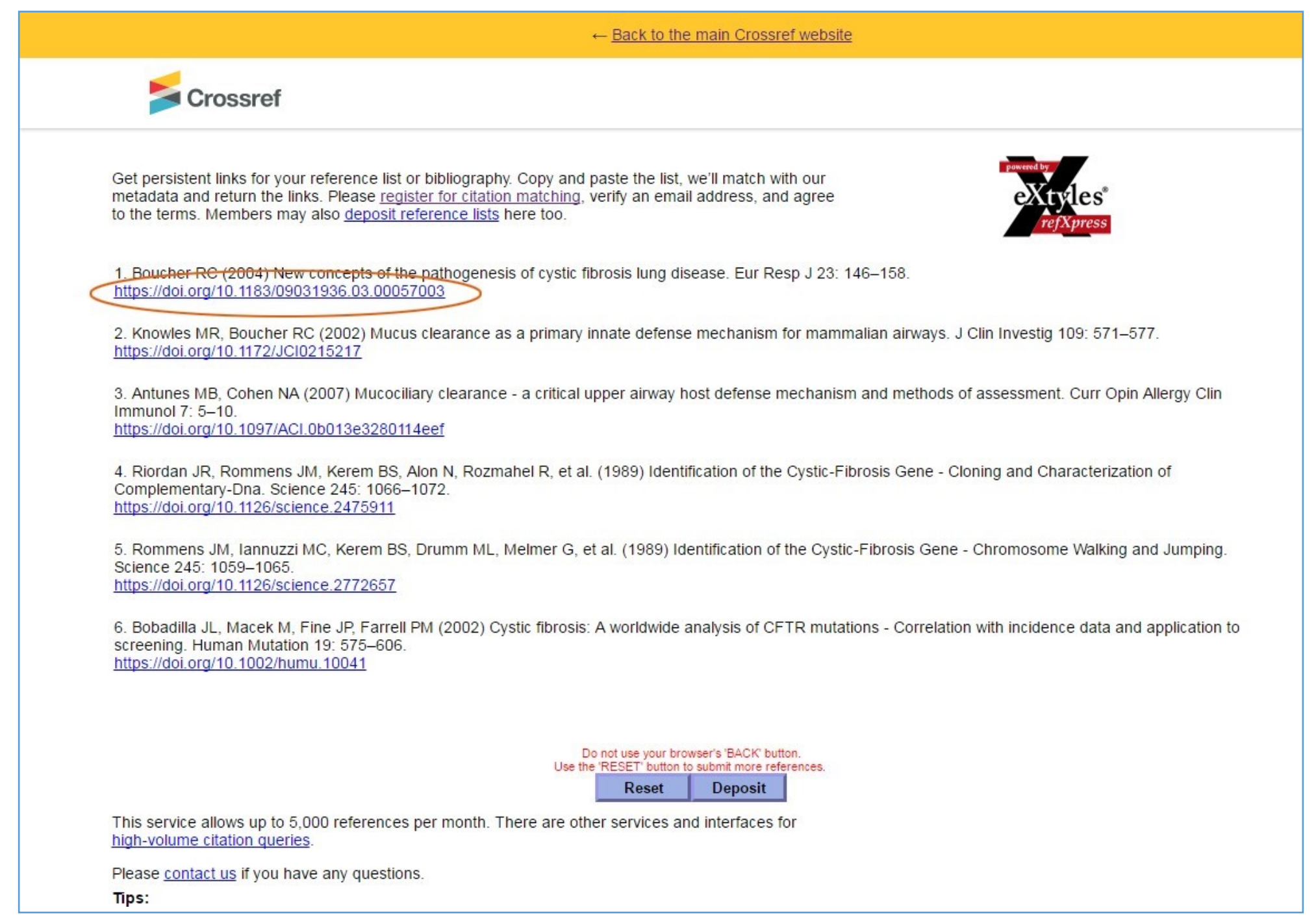

Niels Erik Frederiksen, februar 2017

(Opdatering af tidligere vejledning fra juli 2015) 